\title{
ACCOUNTING ETHICS - AN EMPIRICAL INVESTIGATION OF MANAGING SHORT-TERM EARNINGS
}

\author{
Leonie Jooste \\ School of Accounting, Nelson Mandela Metropolitan University \\ Accepted August 2009
}

\begin{abstract}
Short-term earnings are managed in most, if not all, companies. The management of short-term earnings is vulnerable to misinterpretation, manipulation or deliberate deception even if these misleading accounting practices are prohibited by accounting regulations. Hence, the problem with managing short-term earnings is that it becomes an ethical practice, regardless of who is or may be affected by the practice or the information that flows from it. As a result of the publicity received by Enron and WorldCom on financial failures and fraud, and the subsequent legislation, the Sarbanes-Oxley Act in 2002, students are expected to understand the morality issues of earnings-management practices. Therefore, the ethics of earnings-management practices affect the accounting educator. Accounting students and business managers were surveyed and the findings indicated that there is no significant difference between gender regarding the ethicality of twenty earning management practices. The results, however, show that there is a significant difference between the perceptions of business managers and students regarding the morality of earningsmanagement practices. However, no significant differences were found between genders.
\end{abstract}

JEL M41

\section{1 Introduction}

Earnings-management can be defined as any action on the part of management which affects reported net income and which provides no true economic advantage to the organisation, even if it may be detrimental to the company in the long run (Merchant \& Rockness, 1994:79).

A survey was conducted of the readership of the Harvard Business Review on the acceptability of practices in earning management (Harvard Business Review, 1989). Bruns and Merchant (1990) characterised the results as 'frightening'. The authors observed that where a practice is not explicitly prohibited or where there is a slight deviation from the rules, it seems that it becomes an ethical practice regardless of who might be affected by the practice or the information that flows from it. Bruns and Merchant (1990) agree that anyone who uses information on short-term earnings is vulnerable to misinterpretation, manipulation, or deliberate deception as some of the earnings-management practices can be immoral and unethical.

Many cases of financial fraud and failures in companies have emerged globally. After the major accounting scandal of Enron and WorldCom, and the subsequent demise of Arthur Andersen in America, the question of values and ethics in accounting has become a widely discussed and researched topic. For its 2002 Annual Meeting, the American Accounting Association chose the Quality of Earnings Project as its main theme and, in turn, academic journals have invited research articles focusing on earnings-management practices (Giacomino, Bellovary \& Akers, 2006). Following the scandals, the United States (US) Congress passed the Sarbanes-Oxley Act of 2002 (Corporate Governance in South Africa), that holds executives personally responsible and criminally liable for certifying financial statements (Elias, 2002). Business ethics has 
not only revived academics' and accounting practitioners' interest in ethics and earningsmanagement practices but it also supports the view that there is a lack of ethics and ethical behaviour on the part of businesses and management (Karassavidou \& Glaveli, 2006).

The failure of a company is not simply a matter of accounting and auditing but the involvement of a convergence of factors including personal values, integrity and ethics (Akers, Eaton \& Giacomino 2004). Hence, as a result of the consequences of earnings-management practices and surveys administered in previous studies in the US (Bruns \& Merchant, 1990; Merchant \& Rockness, 1994; Rosenzweig \& Fischer, 1994; Fischer \& Rosenzweig, 1995; Clikeman, Geiger \& O'Connell, 2001; Kaplan, 2001; Elias, 2002; Giacomino et al., 2006), this study conducted a survey with students and business managers to determine their perceptions of the morality aspects of earnings-management and to determine if perceptions differ by gender. This study is similar to the study by Giacomino et al. (2006) where the ethical perceptions of students, business managers and gender were compared.

\section{2}

\section{Literature review}

In 1990, Bruns and Merchant (1990) reported on a questionnaire regarded by auditors as short-term earnings-management situations. The Harvard Business Review (1989) readers were asked to rate 13 earnings-management situations. The authors (Bruns \& Merchant, 1990) observed that they were shocked with the result, as some of the earnings-management situations could be labelled as immoral and clearly unethical. Despite the general utilisation of earnings-management, widespread confusion and disagreement remain over what the concept of earnings quality should include.

Prior to the study by Bruns and Merchant (1990), researchers and accounting practitioners paid little attention to the morality of short-term earnings-management. Healy (1985) stated that reported net earnings may often be the product of deliberate choices between various accounting treatments and business options.
These earnings-management actions can be harmful, and mislead financial statement users and may be precursors of more serious and illegal activities (Healy, 1985:106-107). Bernstein \& Siegel (1979) agreed that to assess the true earnings power of a company, a determination of the quality of earnings must be made.

October 2001 saw the first of many reports on significant accounting irregularities in financial statements issued by Enron, which at the time was the seventh largest company on the Fortune 500. The scandal soon focused attention on Arthur Andersen, who signed off annual financial statements. The list of companies involved in investigations of financial irregularities increased and included companies such as WorldCom, Computer Associates, Global Crossing, Tyco, K-Mart, Xerox, Halliburton, Bristol-Myers Squibb, Adelphia, Lucent Technologies, HealthSouth, and Freddie Mac. Every Big 5 accounting firm has been involved in these investigations to some extent, of which Arthur Andersen was the only firm to receive a criminal conviction (Comunale, Sexton \& Gara, 2006).

The scandals destroyed the credibility of financial analysts and led to the collapse of a Big 5 accounting firm. With the highly publicised financial frauds and failures, compelling questions have been raised about the role of public accountants. Therefore, the accounting profession has emphasised the importance of the concepts of earnings-management and, as a result, many accounting journals have invited and published research articles that deal with earnings management (Elias, 2002).

In response to corporate scandals and financial fraud, researchers embarked upon research in earnings-management practices and corporate ethical values, similar to that of Bruns and Merchant (1990). The questionnaire of Bruns and Merchant (1990) was used by Merchant and Rockness (1994) where general managers, staff managers, operation-unit controllers, and internal auditors were sampled. Rosenzweig and Fischer (1994) found that respondents with more years of experience and higher levels of responsibility (partners) judged practices less harshly than accountants with less than six years experience and at the entry and junior levels. 
Fischer and Rosenzweig (1995) surveyed undergraduate students, MBA students, and practising accountants on their attitudes on the ethical acceptability of earnings-management practices and found that operating manipulations were judged less ethically by accounting practitioners. Clikeman et al. (2001) surveyed students and made comparisons by culture, based on national origin, and gender. However, in their study, no significant differences were found.

Elias (2002) surveyed students, faculty, accountants in industry and certified public accountants (CPAs) and reported that accountants in practice were more lenient than accounting students and faculty were.

In many companies, concern for the bottom line or 'making the numbers' seems to override any concern for ethical values (Verschoor, 2002). Priest (2002) notes that unethical earningsmanagement practices could be attributed to the failure of corporate ethics. Furthermore, Khaled ElMoatasem Abdelghany (2005) found that companies should apply more than one measure for the quality of earnings, as management may manipulate the earnings to achieve predetermined targets. Karassavidou and Glaveli (2006) investigated the ethical orientation of undergraduate business students in Greece. The authors (Karassavidou \& Glaveli, 2006) found that academic dishonesty is positively related to students' attitudes towards unethical managers' behaviour in the business context and that females appear to have higher ethical standards.

Deloitte and Touche (2002) list the core values of a company as 'integrity, objectivity, independence and technical excellence' and that the foundation of a company is employees with strong values. They also highlight the importance of the individual values of employees. Accordingly, Deloitte and Touche (2002) aims to employ outstanding professionals and instil in their employees the sense that they must always act with integrity and to do what is right. But, as scandals of public companies become exposed, it becomes evident that people and not accounting are responsible for the major losses suffered by innocent investors. Where people are to blame, the assumption can be made that they are people with poor ethical values and integrity (Akers et al., 2004).

However, although a professional code of conduct exists to deal with the behaviour of the accounting profession, an individual's behaviour is still affected by his or her personal values, because behaviour is influenced by personal values and not by a code of ethics (Eaton \& Giacomino, 2000, 2001). Therefore, having a code of ethics is not enough or has little meaning (Verschoor, 2002; Boyd, 2004). This is evident in the Arthur Andersen case (Akers et al., 2004) where Toffler, a former partner of Arthur Andersen, points out that most companies have codes of ethics and that corporate values are guided by honesty, integrity, trust, respect and possibly commitment or teamwork. However, the results turned out differently. Woo (2003) agrees and states that knowing what is right is not the same as doing what is right.

Business ethics has consequences for the accounting educators as the values extolled by educators may also not necessarily be internalised by students. In this regard, many business schools have initiated new business ethics courses, developed cases, conducted workshops and held seminars in ethics. Woo (2003), however, raises the question whether business schools can teach MBA students right from wrong when the average student is between 26 and 28 years old. Courses in ethics should be included in undergraduate studies.

Giacomino et al. (2006) surveyed students and business managers to measure their perception of specific earnings-management actions. The questionnaire was similar to that used by Bruns and Merchant (1990) but included 20 items relating to ten earnings-management practices. The aim was to propose a methodology to incorporate in accounting programmes to measure and change students' personal values. This study proceeds with a similar study as Giacomino et al. (2006) to survey short-term earnings-management practices.

3

\section{Research methodology}

The main objective of this study was to conduct a survey of students at the Nelson Mandela 
Metropolitan University (NMMU), and of business managers to measure their perceptions about the morality of specific earningsmanagement actions. The aim of the study was to determine whether students and business managers have different views about the ethics of earnings-management practices and to determine if the perceptions of respondents differ by gender.

\subsection{The research questionnaire}

The questionnaire involved practices of shortterm earnings-management and was completed by 360 respondents. The practices involved the choice and timing of operating events and the choice and timing of recognition of specific revenues and expenses. The same questionnaire was used as in the Giacomino et al. (2006) survey. No additional questions were raised and no wording was changed, however, the currency (\$) was changed to rand (R).

The respondents were informed that the questionnaire referred to a R1 billion company consisting of different divisions. Each division had a turnover of R100 million and net profits before taxation of R12 million with a JanuaryDecember financial year. The respondents were required to rate each question on a five-point Likert scale ranging from 1 to 5 as follows:

$1=$ Ethical practice.

$2=$ Questionable practice. I would not say anything to the person involved, but it makes me uncomfortable.

$3=$ Minor infraction. The person should be warned not to engage in the practice again.

$4=$ Serious infraction. The person should be severely reprimanded.

$5=$ Totally unethical. The person should be fired.

In Table 1, 20 actions related to ten earningsmanagement practices are listed. Annexure 1 depicts the actual questionnaire given to the respondents.

\section{Table 1}

Short-term earnings-management practices

\begin{tabular}{|l|l|}
\hline \multicolumn{2}{|c|}{ Action - Short-term earnings-management practices } \\
\hline 1. & Paint ahead of schedule. \\
\hline 2a. & Defer discretionary expenses to meet quarterly budget. \\
\hline 2b. & Defer discretionary expenses to meet annual budget. \\
\hline 3. & Defer discretionary expenses to meet annual budget. \\
\hline 4a. & Credit that has more liberal terms to reach budget target. \\
\hline 4b. & Work overtime to reach budget target. \\
\hline 4c. & Sell excess assets to reach budget target. \\
\hline 5a. & Prepay expenses to reduce income by R60 000. \\
\hline 5b. & Increase reserve for inventory obsolescence; reduce income R700 000. \\
\hline 6a. & Reduce reserve for inventory obsolescence to continue work. \\
\hline 6b. & Reduce reserve for inventory obsolescence to meet budget target. \\
\hline 7. & Bury scrap costs in 'other expenses', no income effect. \\
\hline 8a. & Request deferred billing for supplier, R30 000. \\
\hline 8b. & Request deferred billing from supplier, R500 000. \\
\hline 9a. & Raise return forecast from 22\% to 35\%, actual $22 \%$. \\
\hline
\end{tabular}




\begin{tabular}{|l|l|}
\hline $9 \mathrm{~b}$. & Raise return forecast from $22 \%$ to $35 \%$, actual $35 \%$. \\
\hline 10a. & Accelerate delivery to customer by 3 days. \\
\hline 10b. & Accelerate delivery to customer by 16 days. \\
\hline 10c. & Accelerate delivery to customer by 28 days. \\
\hline 10d. & Accelerate delivery to customer by 42 days. \\
\hline
\end{tabular}

\subsection{Research method}

This study is a descriptive study in which a questionnaire was used to determine the perceptions of two groups of people, business managers and students, and to determine if the perceptions of respondents differ by gender. As students are potential business managers, this has implications for accounting education as it is not enough to make students merely aware of ethical issues but to include ethics in accounting studies. It is, therefore, of interest to research the morality perceptions of students and business managers on specific earningsmanagement actions.
Table 2 provides a breakdown of the respondents by group and gender. A total of 96 business managers (including 15 chartered accountants) and 264 students were included in the survey. Qualified chartered accountants in Port Elizabeth and MBA students at the NMMU represented business managers, and the second group, the students, were represented by second and third year financial accounting students at the NMMU, enrolled in National Diploma (ND) programmes with financial accounting as one of their major subjects.

Table 2

Demographic data of the respondents

\begin{tabular}{|l|l|r|}
\hline \multicolumn{1}{|c|}{ Respondents } & \multicolumn{1}{|c|}{ Demographic data of the respondents } \\
\hline \multirow{4}{*}{ Groups } & Students & 259 \\
\cline { 2 - 3 } & Business managers (BM) & 74 \\
\cline { 2 - 3 } & Not answered (5 students; 2 BM) & 360 \\
\cline { 2 - 3 } & Total & 179 \\
\hline \multirow{5}{*}{ Gender } & Male & 135 \\
\cline { 2 - 3 } & Female & 46 \\
\cline { 2 - 3 } & Not answered & 360 \\
\cline { 2 - 3 } & Total & \multicolumn{2}{|c|}{. } \\
\hline
\end{tabular}

\subsection{The results}

The frequency distribution of the responses were firstly calculated in total and then by group, for each of the twenty earnings-management actions. Secondly, the mean value of each action was calculated and the responses categorised from 'Totally Unethical' to 'Ethical Practice'. An analysis of variance (t-test) was then used to measure the differences between the respondents.

The overall response showed a significant lack of agreement. Secondly, the dispersion of ratings varied considerably. Furthermore, based on the mean values and the frequency distributions of the responses in Table 3, it was found that: 
- No practice was rated as 'Totally Unethical', with a mean above 4.5

- Not one practice was found to be an 'Ethical Practice' with a mean below 1.5

- Three of the 20 practices were rated as a 'Serious Infraction' with a mean between 3.5 and 4.5
- Twelve practices were rated as a 'Minor Infraction' with a mean between 2.5 and 3.5

- Five practices were rated as a 'Questionable Practice' with a mean between 1.5 and 2.5.

\section{Table 3}

Rating of earnings-management actions

\begin{tabular}{|c|c|c|c|}
\hline Ethical categories & Action & Mean & Std Dev \\
\hline Totally unethical & None & & \\
\hline \multirow[t]{3}{*}{ Serious infraction } & Bury scrap costs in 'other expenses', no income effect (7). & 3.8902 & 1.2601 \\
\hline & Request deferred billing from supplier, R500 000 (8b). & 3.7623 & 1.1813 \\
\hline & Defer supplies expenses by delaying recording invoice (3). & 3.5356 & 1.2321 \\
\hline \multirow[t]{12}{*}{ Minor infraction } & Accelerate delivery to customer by 42 days (10d). & 3.2960 & 1.3144 \\
\hline & $\begin{array}{l}\text { Increase reserve for inventory obsolescence, reduce } \\
\text { income R700 } 000 \text { (5b). }\end{array}$ & 3.2229 & 1.1338 \\
\hline & Request deferred billing for supplier, R30 000 (8a). & 3.2054 & 1.1729 \\
\hline & Defer discretionary expenses to meet annual budget $(2 b)$. & 3.1838 & 1.2452 \\
\hline & Raise return forecast from $22 \%$ to $35 \%$, actual $22 \%$ (9a). & 3.1807 & 1.2157 \\
\hline & Accelerate delivery to customer by 28 days (10c). & 3.0438 & 1.3840 \\
\hline & $\begin{array}{l}\text { Defer discretionary expenses to meet quarterly budget } \\
\text { (2a). }\end{array}$ & 2.9848 & 1.1931 \\
\hline & $\begin{array}{l}\text { Reduce reserve for inventory obsolescence to continue } \\
\text { work (6a). }\end{array}$ & 2.9554 & 1.1924 \\
\hline & Prepay expenses to reduce income by R60 000 (5a). & 2.8905 & 1.3577 \\
\hline & Raise return forecast from $22 \%$ to $35 \%$, actual $35 \%(9 b)$. & 2.8903 & 1.2377 \\
\hline & Accelerate delivery to customer by 16 days (10b). & 2.8156 & 1.0566 \\
\hline & $\begin{array}{l}\text { Reduce reserve for inventory obsolescence to meet budget } \\
\text { target (6b). }\end{array}$ & 2.7025 & 1.3021 \\
\hline \multirow[t]{5}{*}{$\begin{array}{l}\text { Questionable } \\
\text { practice }\end{array}$} & $\begin{array}{l}\text { Credit that has more liberal terms to reach budget target } \\
\text { (4a). }\end{array}$ & 2.4673 & 1.1404 \\
\hline & $\begin{array}{l}\text { Accelerate delivery to customer by } 3 \\
\text { days ( } 10 \mathrm{a}) .\end{array}$ & 2.4585 & 1.2105 \\
\hline & Sell excess assets to reach budget target (4c). & 2.4000 & 1.3228 \\
\hline & Work overtime to reach budget target (4b). & 2.1927 & 1.1838 \\
\hline & Paint ahead of schedule (1). & 1.8720 & 1.0920 \\
\hline Ethical practice & None & & \\
\hline
\end{tabular}


Based on the mean values, it seems that the respondents do not support the acceptability of these practices, since not one practice was deemed an 'Ethical Practice'. For the five practices that were viewed as 'Questionable Practices', the respondents would not say anything to the person involved, although it made them uncomfortable. In addition, for the 12 practices categorised as 'Minor Infractions', the respondents believed that the person involved should be warned not to engage in the practice again. For the three practices rated as 'Serious Infractions', the respondents believed that the person involved should be severely reprimanded and, finally, not one practice was rated as 'Totally Unacceptable' and, therefore, no-one would be fired.

Some of the earnings-management actions are rated by the respondents as ethical, whereas others are unethical, some being to a certain degree unethical. Giacomino et al. (2006) found that respondents were influenced by dollar amounts, timing of transactions and the methods used in the practices. In this study it was also interesting to find how respondents were affected by qualifiers in some of the practices.

For many of the practices, it was found that respondents were influenced by the method, purpose, materiality and timing of the action. Managing short-term earnings by accounting methods was viewed less favourably than changing operating decisions or procedures. Painting ahead of schedule (action 1 ) was rated as 'Questionable' whereas expenses postponed into the next quarter (action 2a) was rated as a 'Minor Infraction'. Furthermore, the method used by increasing profits by offering extended credit terms (action 4a; Mean 2.4673) was viewed as less acceptable than increasing earnings by working overtime (action 4b; Mean 2.1927) or selling off excess assets (action 4c; Mean 2.4).

The direction or effect on earnings was viewed less favourably if earnings increased than when earnings decreased. Paint ahead of schedule (action 1) was rated more favourably than increasing earnings by postponing expenses to the next financial period (action 2b). In actions $8 \mathrm{a}$ (request deferred billing for supplier, R30 000) and $8 \mathrm{~b}$ (request deferred billing for supplier, R500 000), materiality became a factor.

Where the amount involved is R30 000, the respondents rate action 8a as a 'Minor Infraction' (3.2054). However, where the amount is R500 000 in action 8b, it is rated as a 'Serious Infraction' (3.7623). Similarly with the timing of transactions, where the delivery date was accelerated in excess of 3 days (action 10a), the earnings-management practice was viewed more seriously and rated as a 'Serious Infraction' in actions $10 \mathrm{~b}$ (16 days), 10c (28 days) and $10 \mathrm{~d}$ (42 days). Similarly, managing short-term earnings at the end of an interim quarterly report is viewed as more acceptable (2.9848) than engaging in the same activity at the end of the financial year (3.1838).

Table 4 outlines the mean values of the survey to investigate significant differences by gender and by group.

Table 4

Mean values of significant differences by group and by gender (t-test)

\begin{tabular}{|l|l|c|c|c|c|}
\hline \multicolumn{2}{|c|}{ Action } & \multicolumn{2}{c|}{ Group } & \multicolumn{2}{c|}{ Gender } \\
\cline { 3 - 6 } & \multicolumn{1}{|c|}{ S } & BM & M & F \\
\hline 1 & Paint ahead of schedule. & 1.8529 & 1.9239 & 1.9709 & 1.7846 \\
\hline $2 \mathrm{a}$ & $\begin{array}{l}\text { Defer discretionary expenses to meet } \\
\text { quarterly budget. }\end{array}$ & 2.9091 & 3.0879 & 2.9880 & 2.9380 \\
\hline $2 \mathrm{~b}$ & $\begin{array}{l}\text { Defer discretionary expenses to meet } \\
\text { annual budget. }\end{array}$ & 3.1360 & 3.2209 & 3.1768 & 3.1613 \\
\hline 3 & $\begin{array}{l}\text { Defer supplies expenses by delaying } \\
\text { recording invoice. }\end{array}$ & 3.4880 & 3.6596 & 3.5028 & 3.4853 \\
\hline
\end{tabular}




\begin{tabular}{|c|c|c|c|c|c|}
\hline $4 \mathrm{a}$ & $\begin{array}{l}\text { Credit that has more liberal terms to reach } \\
\text { budget target. }\end{array}$ & 2.4142 & 2.6444 & 2.4737 & 2.4077 \\
\hline $4 b$ & Work overtime to reach budget target. & $\begin{array}{c}* \\
2.2586\end{array}$ & 2.0341 & 2.2426 & 2.1339 \\
\hline $4 c$ & Sell excess assets to reach budget target. & 2.4292 & 2.3034 & 2.4162 & 2.3609 \\
\hline $5 a$ & $\begin{array}{l}\text { Prepay expenses to reduce income by } \\
\text { R60 } 000 .\end{array}$ & 2.6815 & 3.4022 & 2.8914 & 2.9407 \\
\hline $5 b$ & $\begin{array}{l}\text { Increase reserve for inventory } \\
\text { obsolescence, reduce income R700 } 000 \text {. }\end{array}$ & 3.0905 & $\begin{array}{c}* \\
3.5275\end{array}$ & 3.1618 & 3.2782 \\
\hline $6 a$ & $\begin{array}{l}\text { Reduce reserve for inventory obsolescence } \\
\text { to continue work. }\end{array}$ & 2.7615 & $\begin{array}{c}* \\
3.4333\end{array}$ & 2.8947 & 2.9466 \\
\hline $6 b$ & $\begin{array}{l}\text { Reduce reserve for inventory obsolescence } \\
\text { to meet budget target. }\end{array}$ & 2.3857 & $\begin{array}{c}* \\
3.4535\end{array}$ & 2.7250 & 2.7154 \\
\hline 7 & $\begin{array}{l}\text { Bury scrap costs in 'other expenses', no } \\
\text { income effect. }\end{array}$ & 3.7984 & 4.1648 & 3.9379 & 3.8284 \\
\hline $8 a$ & $\begin{array}{l}\text { Request deferred billing for supplier, } \\
\text { R30 } 000 .\end{array}$ & 3.0886 & $\begin{array}{c}* \\
3.5217\end{array}$ & 3.2670 & 3.1985 \\
\hline $8 b$ & $\begin{array}{l}\text { Request deferred billing from supplier, } \\
\text { R500 } 000 \text {. }\end{array}$ & 3.7336 & $\begin{array}{c}* \\
3.8409\end{array}$ & 3.8721 & 3.6504 \\
\hline $9 \mathrm{a}$ & $\begin{array}{l}\text { Raise return forecast from } 22 \% \text { to } 35 \% \text {, } \\
\text { actual } 22 \% \text {. }\end{array}$ & 3.0043 & $\begin{array}{c}* \\
3.6889\end{array}$ & 3.0983 & 3.3030 \\
\hline $9 b$ & $\begin{array}{l}\text { Raise return forecast from } 22 \% \text { to } 35 \% \text {, } \\
\text { actual } 35 \% \text {. }\end{array}$ & 2.7009 & $\begin{array}{c}* \\
3.3750\end{array}$ & 2.8929 & 2.9440 \\
\hline $10 \mathrm{a}$ & Accelerate delivery to customer by 3 days. & 2.3421 & $\begin{array}{c}* \\
2.7692\end{array}$ & 2.4524 & 2.5194 \\
\hline $10 \mathrm{~b}$ & Accelerate delivery to customer by 16 days. & 2.7422 & $\begin{array}{c}* \\
3.0337\end{array}$ & 2.8606 & 2.8031 \\
\hline 10c & Accelerate delivery to customer by 28 days. & 2.9333 & $\begin{array}{c}* \\
3.2921\end{array}$ & 3.0904 & 2.9843 \\
\hline $10 d$ & Accelerate delivery to customer by 42 days. & 3.2345 & $\begin{array}{c}* \\
3.4270\end{array}$ & 3.2754 & 3.3622 \\
\hline
\end{tabular}

* Difference in mean values, using the t-test, is significant at 5 per cent level.

\subsection{Comparing differences between gender}

It was found that for most of the earningsmanagement practices, the males viewed the practices less favourably than the females did. When comparing the responses by gender, it was found that males have stricter views than females for 13 of the 20 practices (the mean values of male respondents were higher than the mean values of females). In seven of the 20 practices females had higher mean values than male respondents, and in six cases female 
and male respondents rated the earningsmanagement actions the same. Not one of 20 actions has a significant difference between genders. Therefore, it can be said that there are no significant differences by gender regarding the ethicality of the 20 earnings-management practices. Both Clikeman et al. (2001) and Giacomino et al. (2006) reach similar findings from their surveys.

\subsection{Comparing differences between groups}

With respect to group differences, the results show that for most of the short-term earningsmanagement practices the business managers tended to view the practices less favourably than the students did. Business managers have a stricter view than the students do in 18 of the 20 practices, whereas students viewed only two practices more strictly. Fourteen practices were significantly different $(p>0.05)$. For the two practices where the students had the stricter views, only one was significant. Therefore, the assumption can be made that there are significant differences between business managers and students regarding the ethicality of earningsmanagement practices. Giacomino et al. (2006) found undergraduate students to be stricter than business managers were.

A total of 360 respondents completed the survey and the greatest concern of the findings was the total lack of agreement. Based on the mean values, not one action was unanimously rated as either ethical or unethical, but varied from 'Serious Infractions' to 'Questionable Practice'. Therefore, the judgements about all earnings-management practices varied considerably.

\section{4}

\section{Conclusions and recommendations}

Earnings figures should have integrity and should not be the product of manipulations with the intention to purely increase the reported income of a company. They should also be reliable, in the sense that they must be an indication of the quality of earnings and future earnings (Bernstein \& Siegel, 1979).
Casual observers of the financial reporting process may assume that time, laws, regulations and accounting standards have restricted accounting practices to those that are moral, ethical, fair and precise. But most managers know that managing short-term earnings can be part of their job (Bruns \& Merchant, 1990). In this study, it was found that there is a high level of disagreement among business managers and students regarding which short-term earnings-management practices are ethical. Business managers generally took a stricter position than students did. Students tended to judge the practices more ethically than business managers did, whereas males were inclined to view the practices less favourably ethically than females did.

The results of this study represent a case study only where accounting students and business managers have been surveyed. The results of this study may enable accounting educators to understand what students feel and how they may react to such earning-management practices. Furthermore, the results of this study need to be interpreted in the light of possible weaknesses. First of all, the respondents in this study may not be representative of students and business managers in South Africa. Business managers were found to have stricter views than students do. This may be a due to the fact that students have fewer risks than business managers and also the possibility that students may not fully understand the wording of the questionnaire on earnings-management practices. Furthermore, accounting students have no prior business ethics education.

The results of this study, similar to those of other studies (Fischer \& Rosenzweig, 1995; Giacomino et al., 2006), have implications for academia. Accounting students need more exposure and understanding of earningsmanagement. There should also be regular reports of fraudulent practices as a result of earnings-management by the media and academic journals. Fischer and Rosenzweig (1995) suggest that greater emphasis be placed in the accounting curricula on earningsmanagement practices. Although difficult, it should be integrated into business courses or a separate business ethics course or an 
accounting course taught by accounting and ethics academia. In this regard The South African Institute of Chartered Accountants (2007) states in their education policy that the education and training of professional accountants must provide a foundation of knowledge, skills and professional values and ethics that will enable students to continue to learn and adapt to changes throughout their professional lives.

Giacomino et al. (2006) suggest that the 'real-world' aspects of earnings-management practices be enhanced and that experienced business professionals become an integral part of accounting courses. Differences between business managers and students should be minimised as conflicting opinions begin to develop during undergraduate business education. Students appear to begin adopting the attitudes of their professional reference groups before they even commence their professional careers. By using experienced professionals during lectures and by making discussion of earning more realistic, the differences between students and business managers may be reduced.

Since the study by Bruns and Merchant (1990), research regarding the morality of earnings-management practices has increased. The importance of ethical practices has been recognised owing to the highly publicised financial failures and frauds such as Enron and WorldCom, and subsequent legislation to comply with, for example, Sarbanes-Oxley and Corporate Governance.

This study can serve as a starting point and the survey can be repeated in later years to determine if there are changes in the ethical views of accounting students. Furthermore, if courses are introduced to address aspects of earnings management, a survey can determine whether it contributed towards changing the ethical views of the students or if there is still room for improvement. However, Woo (2003) questions whether ethical courses included in curricula will support accounting students to have the will to do what is right once they are in the corporate setting.

The Enron and WorldCom scandals and the demise of Arthur Anderson have received worldwide publicity. Since then, there has been a demand for sound accounting practices and corporate governance. However, it is also important to determine whether the scandals and pressures to adhere to corporate governance have changed views on moralities regarding earnings-management practices. In this regard, harmonising reward structures with ethical principles is an area where management accountants and financial managers can provide guidance (Verschoor, 2002).

Bruns and Merchant (1990) suggest the key to moral behaviour is the obligation to look beyond self-interest and to focus on the concerns of others. The morality of doing otherwise is questionable. Deloitte and Touche (2002) highlight the importance of the individual values of employees. Values and responsible behaviour can be reinforced through a company's procedures, policies and training so that when staff members encounter challenging situations at work, they should be guided by these values (Messmer, 2003).

\section{References}

AKERS, M.D., EATON, T.V. \& GIACOMINO, D.E. 2004. Measuring and changing the personal values of accounting students. Journal of College Teaching \& Learning, 1(4): 63-70.

BERNSTEIN L.A. \& SIEGEL, J.G. 1979. The concept of earnings quality. Financial Analysts Journal, 35:72-75.

BOYD, C. 2004. The last straw. Business Ethics Quarterly, 13(3): 581-592.

BRUNS, W.J. \& MERCHANT, K.A. 1990. The

dangerous morality of managing earnings. Management Accounting, 72(2): 22-25.

CLIKEMAN, P., GEIGER, M. \& O'CONNELL, B. 2001. Student perceptions of earnings management: The effects of national origin and gender. Teaching Business Ethics, 5(4): 389-410.

COMUNALE, C.L., SEXTON, T.R. \& GARA, S.C. 2006. Professional ethical crises. A case study of accounting majors. Managerial Auditing Journal, 21(6): 636-656.

DELOITTE \& TOUCHE. 2002. Integrity \& Quality.

New York: Deloitte \& Touche LLP.

EATON, T.V. \& GIACOMINO, D.E. 2000. Personal values of business students: Differences by gender and discipline. Research on Accounting Ethics, 7: 83-102. EATON, T.V. \& GIACOMINO, D.E. 2001. An examination of personal values: Differences between 
accounting students and managers and differences between genders. Teaching Business Ethics, 5: 213-229. ELIAS, R. 2002. Determinants of earnings management ethics among accountants. Journal of Business Ethics, 40(1): 33-45.

FISCHER, M. \& ROSENZWEIG, K. 1995. Attitudes of students and accounting practitioners concerning the ethical acceptability of earnings management.

Journal of Business Ethics, 14(6): 433-444.

GIACOMINO, D.E., BELLOVARY, J.L. \& AKERS, M. 2006. The ethics of managing short-term earnings: Business managers and business students have few problems with earnings management practices. Journal of College Teaching \& Learning, July: 57-71.

HEALY, P.M. 1985. Effects of bonus schemes on accounting decisions. Journal of Accounting and Economics, 7(1-3): 85-107.

HARVARD BUSINESS REVIEW. 1989. Ethics test for everyday managers. Harvard Business Review, March-April: 220-221.

KAPLAN, S. 2001. Ethically related judgements of observers of earnings management. Journal of Business Ethics, 32(4):285-298.

KARASSAVIDOU, E. \& GLAVELI, N. 2006. Towards the ethical or the unethical side? An explorative research of Greek business students' attitudes.

International Journal of Educational Management, 20(5): 348-364.
KHALED ELMOATASEM ABDELGHANY. 2005.

Measuring the quality of earnings. Managerial Auditing Journal, 20(9): 1001-1015.

MERCHANT, K.A. \& ROCKNESS, J. 1994. The ethics of managing earnings: an empirical investigation. Journal of Accounting and Public Policy, 13: 79-94.

MESSMER, M. 2003. Does your company have a code of ethics? Strategic Finance, April:13-14.

PRIEST, S. 2002. The disconnect in ethics training.

Across The Board, 39(5): 51-52.

ROSENZWEIG, K. \& FISCHER, M. 1994. Is

managing earnings ethically acceptable? Management Accounting, 75(9): 31-34.

SAICA. 2007. SAICA in search of excelling accounting students. Available at: https://www.saica.co.za/default. asp?redir $=\% 2 \mathrm{FDisplayContent} \% 2 \mathrm{Easp} \% 3 \mathrm{FContentP}$ ageID\%3D979 [Accessed 12 July 2007].

VERSCHOOR, C. 2002. It isn't enough to just have a code of ethics. Strategic Finance, December: 22-24. WOO, C.J. 2003. Personally responsible. BizEd, May/ June: 22-27.

\section{Acknowledgement}

Professors Don Giacomino and Michael Akers are specially acknowledged for encouraging and initiating this study. 


\section{Annexure 1}

\section{QUESTIONNAIRE ON ETHICS}

This questionnaire includes short descriptions of a variety of actions that individuals have taken. Some of these actions are clearly ethical. Others are judged by some or most people to be unethical, and the judgments as to the degree of severity of the infraction can vary widely.

Please indicate your judgment as to the acceptability of each of the practices using the following scale:

1. Ethical practice

2. Questionable practice. I would not say anything to the person involved, but it makes me uncomfortable.

3. Minor infraction. The person should be warned not to engage in the practice again.

4. Serious infraction. The person should be severely reprimanded.

5. Totally unethical. The person should be fired.

(Assume that the divisions referred to are part of a R1 billion corporation, which has a January-December financial year. Each division has annual sales of R100 million, with annual before-tax operating profit of R12 million.)

Answer each question separately. (Assume the incidents are independent.)

\begin{tabular}{|c|c|c|c|c|c|c|}
\hline \multicolumn{2}{|c|}{ QUESTIONNAIRE ON ETHICS } & \multicolumn{3}{|c|}{$\begin{array}{l}\text { Ethical } \\
\text { Practice }\end{array}$} & \multicolumn{2}{|c|}{$\begin{array}{r}\text { Totally } \\
\text { Unethical }\end{array}$} \\
\hline & Action & 1 & 2 & 3 & 4 & 5 \\
\hline 1. & $\begin{array}{l}\text { The division's buildings were scheduled to be painted in } 2002 \text {. } \\
\text { Since the division's profit performance was way ahead of budget } \\
\text { in 2001, however, the division general manager (GM) decided to } \\
\text { have the work done in 2001. Amount: R150 } 000 \text {. }\end{array}$ & 1 & 2 & 3 & 4 & 5 \\
\hline \multirow[t]{3}{*}{2.} & $\begin{array}{l}\text { The GM instructed his employees to defer all discretionary } \\
\text { expenditures (e.g., travel, advertising, hiring, maintenance) into } \\
\text { the next accounting period so that his division could make its } \\
\text { budgeted profit targets. Expected amount of deferral: R150 } 000 \text {. }\end{array}$ & & & & & \\
\hline & $\begin{array}{l}\text { a. The expenses were postponed from February and March to } \\
\text { April in order to make the first quarter target. }\end{array}$ & 1 & 2 & 3 & 4 & 5 \\
\hline & $\begin{array}{l}\text { b. The November and December expenses postponed to January } \\
\text { in order to make annual target. }\end{array}$ & 1 & 2 & 3 & 4 & 5 \\
\hline 3. & $\begin{array}{l}\text { On December } 15 \text {, a clerk in the division placed an order for } \\
\text { R3 } 000 \text { worth of office supplies and the supplies were delivered } \\
\text { on December } 29 \text {. This order was a mistake because the division } \\
\text { GM had ordered that no discretionary expenses be incurred for } \\
\text { the remainder of the fiscal year, and the accounting policy manual } \\
\text { states that office supplies are to be recorded as an expense when } \\
\text { delivered. The division GM learned what had happened, however, } \\
\text { and to correct the mistake, he ordered the accounting department } \\
\text { not to record the invoice until February. }\end{array}$ & 1 & 2 & 3 & 4 & 5 \\
\hline
\end{tabular}




\begin{tabular}{|c|c|c|c|c|c|c|}
\hline \multirow[t]{4}{*}{4.} & $\begin{array}{l}\text { In September, a GM realized that the division would need strong } \\
\text { performance in the last quarter of the year in order to reach its } \\
\text { budget targets. }\end{array}$ & & & & & \\
\hline & $\begin{array}{l}\text { a. He decided to implement a sales program offering liberal } \\
\text { payment terms to pull some sales that would normally occur } \\
\text { next year into the current year; customers accepting delivery } \\
\text { in the 4th quarter would not have to pay the invoice for } 120 \\
\text { days. }\end{array}$ & 1 & 2 & 3 & 4 & 5 \\
\hline & $\begin{array}{l}\text { b. He instructed manufacturing to work overtime in December } \\
\text { so that everything possible could be shipped by the end of the } \\
\text { year. }\end{array}$ & 1 & 2 & 3 & 4 & 5 \\
\hline & c. He sold some excess assets and realized profit of R40 000 . & 1 & 2 & 3 & 4 & 5 \\
\hline
\end{tabular}

5. At the beginning of December 2001, a GM realized that the division would exceed its budgeted profit targets for the year.

a. He ordered his controller to prepay some expenses (e.g., hotel rooms, exhibit expense) for major trades show to be held in March 2002 and to book them as 2001 expense. Amount: R60 000.

b. He ordered his controller to develop the rationale for increasing the reserve for inventory obsolescence. By taking a pessimistic view of future market prospects, the controller was able to identify R700 000 worth of finished goods that conservative accounting would say should be fully reserved (i.e., written off), even though the GM was fairly confident the inventory would still be sold at a later date at close to full price.

\begin{tabular}{|l|l|l|l|l|}
\hline & & & & \\
\hline 1 & 2 & 3 & 4 & 5 \\
\hline & & & & \\
\hline & 2 & 3 & 4 & 5 \\
\hline
\end{tabular}

6. The next year, the division described in question $5 \mathrm{~b}$ sold 70 per cent of the written-off inventory, and a customer had indicated some interest in buying the rest of that inventory the following year. The GM ordered his controller to prepare the rationale for reducing the reserve for obsolescence by R210,000 (i.e., writing up the previously written-off goods to full cost). The GM's motivation for recapturing the profit was:

a. To be able to continue working on some important product development projects that might have had to be delayed due to budget constraints.

b. To make budgeted profit targets.

\begin{tabular}{|l|l|l|l|l|}
\hline 1 & & & & \\
& & & & \\
\hline 1 & 2 & 3 & 4 & 5 \\
\hline 1 & 2 & 3 & 4 & 5 \\
\hline
\end{tabular}

7. In July 2002, a GM noticed that scrap costs in the plant were running way ahead of plan. So that senior management would not become alarmed, he instructed his controller to "bury" most of the scrap costs in other expense accounts where they would not be noticed. Over the remainder of the year, the controller buried approximately R60,000 of scrap costs. Effect on net income: zero.

\begin{tabular}{|l|l|l|l|l|}
\hline & & & & \\
1 & 2 & 3 & 4 & 5 \\
\hline
\end{tabular}




\begin{tabular}{|c|c|c|c|c|c|c|}
\hline \multirow[t]{3}{*}{8.} & $\begin{array}{l}\text { In November 2001, a division was straining to meet budget. The } \\
\text { GM called the engagement partner of a consulting firm that was } \\
\text { doing some work for the division and asked that the firm not send } \\
\text { an invoice for work done until the next financial year. The partner } \\
\text { agreed. Estimated work done but not invoiced: }\end{array}$ & & & & & \\
\hline & a. $\mathrm{R} 30000$ & 1 & 2 & 3 & 4 & 5 \\
\hline & b. R500 000 & 1 & 2 & 3 & 4 & 5 \\
\hline \multirow[t]{3}{*}{9.} & $\begin{array}{l}\text { A GM had an idea for a new product. She asked her marketing } \\
\text { people to conduct some focus group interviews and a field study } \\
\text { to determine the market potential, and she asked her controller } \\
\text { to estimate the costs of entering the market. The projections } \\
\text { promised only a } 22 \text { per cent return when the desired return for } \\
\text { his business was } 35 \text { per cent. However, still convinced that the } \\
\text { product was a good idea, the manager "jacked up" the sales } \\
\text { projections and "shaved" the cost estimates to show a forecasted } \\
35 \text { per cent return. The GM's superiors were preoccupied with } \\
\text { other problems, and they did not question the projections. Thus } \\
\text { the new product was approved. }\end{array}$ & & & & & \\
\hline & $\begin{array}{l}\text { a. After six months of sales, the product earned a } 22 \text { per cent } \\
\text { return. }\end{array}$ & 1 & 2 & 3 & 4 & 5 \\
\hline & $\begin{array}{l}\text { b. After six months of sales, the product earned a } 35 \text { per cent } \\
\text { return. }\end{array}$ & 1 & 2 & 3 & 4 & 5 \\
\hline \multirow[t]{5}{*}{10.} & $\begin{array}{l}\text { At the end of December, a division was struggling to meet its } \\
\text { profit targets. The GM told his production manager to ship } \\
\text { some customer orders early so that the associated revenue and } \\
\text { profits could be recognized in the current year. The items were } \\
\text { in inventory, and expected delivery times were two days. The } \\
\text { customers' firm delivery dates were: }\end{array}$ & & & & & \\
\hline & a. January 3 & 1 & 2 & 3 & 4 & 5 \\
\hline & b. January 14 & 1 & 2 & 3 & 4 & 5 \\
\hline & c. January 28 & 1 & 2 & 3 & 4 & 5 \\
\hline & d. February 12 & 1 & 2 & 3 & 4 & 5 \\
\hline
\end{tabular}

\section{DEMOGRAPHICS:}

Gender: Female Male

Qualification: 